\title{
Long-term evaluation of the prognosis of straight and tapered implant with resorbable blast media surface: Retrospective clinical study
}

\author{
Won-Woong Jang, Dong-Woo Kang, Young-Kyun Kim*
}

Department of Oral and Maxillofacial Surgery, Section of Dentistry, Seoul National University Bundang Hospital, Seongnam, Korea

\begin{abstract}
To evaluate the clinical effectiveness of the straight (Osstem GS II) and tapered body (Osstem GS III) implant system. The survival rate and marginal bone loss of 101 implants placed in 36 patients were evaluated retrospectively. In Department of Oral and Maxillofacial Surgery, Seoul National University Bundang Hospital analyzed the medical records of patients who had completed the implant placement between 2005 and 2010. Sex, implant location, diameter and length were investigated. Also, implant survival rate, marginal bone loss, complications were analyzed. The amount of marginal bone loss was measured at 1 year after prosthetics placement and at the last follow up, by panorama and periapical radiography. An independent t-test was used for the analysis of the association of marginal bone loss of GS II and GS III ( $p=0.05$ ). Out of the 101 implants, which were done on 36 people, 8 implants failed and survival rate was $92.1 \%$. Marginal bone loss at 1 year after prosthetics placement was $0.23 \mathrm{~mm}$ in GS II, and $0.05 \mathrm{~mm}$ in GS III. At the last follow up, marginal bone loss was $0.51 \mathrm{~mm}$ in GS II and $0.29 \mathrm{~mm}$ in GS III. Statistically analyzing the long-term marginal bone loss difference between GS II and GS III implant system, the $p$-value was 0.756 and there was no statistically significant difference between the two. Long-term clinical outcomes of domestic implants by implant systems Osstem GS II and GS III have been satisfactory, and no significant difference in marginal bone loss was observed.
\end{abstract}

Key Words: Implant, Marginal bone loss, Straight, Tapered

(c) This is an open-access article distributed under the terms of the Creative Commons Attribution Non-Commercial License (http://creativecommons.org/licenses/by-nc/4.0) which permits unrestricted noncommercial use, distribution, and reproduction in any medium, provided the original work is properly cited.

\section{서 론}

현재 전 세계적으로 다양한 임플란트 디자인과 표면 처리 제 품들이 출시되고 있으며 계속 개량된 양질의 제품들이 공급되 고 있다. 임플란트의 수요가 늘고 여러 제품들이 출시되고 있는 시점에서 기능적·심미적으로 만족할 수 있으면서 장기간의 좋 은 예후를 보이는 임플란트를 선택하는 것은 매우 중요하다. 임 플란트 고정체는 모양에 따라 크게 straight body와 tapered body 형태로 구분되는데, straight body보다 나중에 출시된 ta- pered body는 발치 후 즉시 식립 시 유용하고, 골질이 약한 곳 에 식립 시 소주골을 치밀하게 다짐으로써 초기 고정을 우수하 게 해준다는 장점을 가진다[1].

임플란트 고정체의 표면 처리 방법으로는 대표적으로 resorbable blast media (RBM), sand-blasted and acid-etched (SLA), hydroxyapatite (HA) coating, anodizing surface 등이 있다. RBM은 매우 빠른 속도로 매질(media)을 임플란트 표면에 분사(blast)시켜 거칠게 만드는 방법이다. 최근에는 수산화인회 석(hydroxyapatite)처럼 생체 친화성이 우수한 흡수성 재료를

Received January 22, 2019; Revised February 12, 2019; Accepted February 13, 2019

Corresponding author: Young-Kyun Kim, Department of Oral and Maxillofacial Surgery, Section of Dentistry, Seoul National University Bundang Hospital, 82 Gumi-ro 173beon-gil, Bundang-gu, Seongnam 13620, Korea.

Tel: +82-31-787-7541, Fax: +82-31-787-4068, E-mail: kyk0505@snubh.org

Copyright ๑ 2019, Oral Biology Research Institute 
매질로 사용함으로써 표면 안전성을 확보하였다. SLA 임플란트 는 분사과정을 거치고 난 후, 표면을 강한 산으로 처리하여 임플 란트 표면의 거칠기를 증가시키는 방법이다. HA coating은 임 플란트 표면에 골전도능(osteoconductive)을 지닌 수산화인회 석을 입혀, 골과 임플란트 사이에 강력한 결합을 형성할 수 있도 록 하는 표면 처리 방법이다. Anodizing surface는 임플란트 표 면에서 티타늄 산화층(titanium oxide layer)을 더 두껍고 거칠 게 만들어주는 전기-화학적 과정인 anodizing을 이용해 임플란 트 표면을 처리한 것이다[2,3].

임플란트 고정체 중 상부에 micro-thread를 채택한 임플란트 고정체는 일반적 형태에 비해 임플란트 고정체의 축방향 강도 (axial stiffness)를 증가시키고, 피질골에서 전단 강도(shearing stresses)를 감소시켜 피질골 주위로 응력(stress)을 분산시키는 데 도움을 준다[4].

임플란트-지대주 연결 방식(implant-abutment connection type)에 따라 external connection과 internal connection으로 나눌 수 있고, external connection의 경우 임플란트 상부 보철 물을 단단히 고정하기 위해 대부분의 하중은 나사가 부담하게 되는데, 최근에는 많이 사용되지 않는다. Internal connection 의 경우 지대주의 원뿔 모양 경사 부위가 임플란트 내면과 완전 히 접촉하게 되면서 안정성이 증가한 양상을 보인다[5].

대한민국의 Osstem Implant사에서는 오래 전 straight body 를 가진 GS II system과 tapered body를 가진 GS III system을 출시하였으며 표면은 모두 RBM 처리가 되어 있다. 이는 최근 많이 사용되고 있는 TS system 개발의 기반을 제공하였다. 현재 는 단종된 상태이지만 과거에 식립되었던 GS II, GS III system 의 장기 예후를 평가해 보는 것은 TS system의 예후와 개선된 장점들을 파악할 수 있는 중요한 근거가 될 것이라고 판단되어 본 연구를 시행하게 되었다.

\section{대상 및 방법}

본 연구는 분당서울대학교병원 생명윤리심의위원회의 승인 하에 진행되었다(승인번호: B-1811/505-114).

\section{연구 대상 임플란트}

본 연구에서 사용된 오스템 임플란트 시스템은 GS II (Osstem, Busan, Korea)와 GS III (Osstem)이며 모두 RBM 표면 처리를 한 bone level fixture로서 internal hex와 $11^{\circ}$ morse taper connection 방식을 채택하고 있다. GS II는 macro와 micro 나사산을 잘 조화시켜 피질골과 해면골에서 모두 우수한 안정도를 얻을 수 있도록 하였고, straight body 형태여서 임플 란트 깊이 조절이 용이하고 훌륭한 self-tapping 능력을 가진다. GS III는 tapered body 형태로서, 즉시 및 조기 하중에 사용될 수 있는 훌륭한 초기 안정성을 보이며 골질이 약한 상악 구치부 에서 골밀도를 치밀하게 하면서 식립되는 장점이 있다(Fig. 1).

\section{수술 및 보철 치료}

임플란트 식립 수술은 제조회사의 지침에 따라 1 인의 구강악 안면외과 전문의에 의해 식립되었으며 필요에 따라 골이식이 동반되었다. 1회법과 2회법 식립 여부는 수술 시 임플란트 초 기 안정성과 동반된 골이식술, 골질 등을 고려하여 술자의 판단 하에 결정되었다. 수술 후 임플란트 초기 안정도와 식립 위치 및 골질 등에 따라 상이한 치유 기간을 부여했고, 이후 보철 치료를 진행하였다. 환자들은 최종 보철물 장착 시, 장착 후 6개월 또는 1 년 주기로 정기적으로 내원하여 임상 검사 및 방사선 사진 검 사를 시행하고 치태 관리를 받았다.

\section{평가 방법}

\section{의무기록 분석}

2005년 1월부터 2010년 12월 사이에 임플란트를 식립한 환 자들을 대상으로 의무기록을 검토하여, GS II 또는 GS III 임플 란트 시스템이 식립된 환자들을 선별하였다. 선별된 환자들의 성별, 연령, 임플란트 식립 위치, 골이식 동반 여부, 사용된 골이 식재와 차폐막의 종류, 1 회법 또는 2회법 수술 여부, 식립된 임 플란트의 직경 및 길이, 임플란트 초기 및 이차 안정도, 수술 후

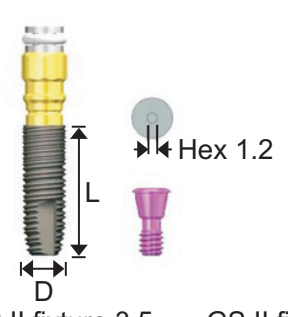

GS II fixture 3.5

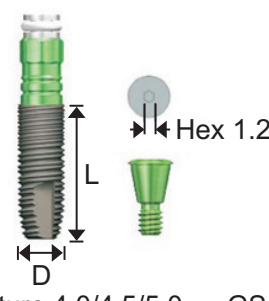

GS II fixture 4.0/4.5/5.0

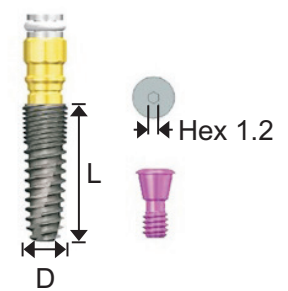

GS III fixture 3.5
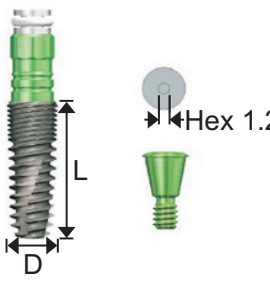

$(\mathrm{mm})$
Fig. 1. Osstem Implant GS II, GS III fixtures. 
초기 혹은 지연 합병증 등을 조사하였다.

\section{임플란트 성공률과 생존율}

임플란트의 성공의 기준은 Albrektsson의 기준에 따라 임플 란트의 동요도가 없고, 임플란트 주위 방사선 투과성 병소가 없 으며, 비가역적 통증, 염증, 괴사성 병변, 마비 등의 증상이 없고 임플란트 식립 1 년 이내에 변연골 소실량이 $1 \mathrm{~mm}$ 이하, 1 년 이 후 연간 평균 변연골 소실량이 $0.2 \mathrm{~mm}$ 이하인 경우로 설정하였 으며, 임플란트 생존의 기준은 식립 후 특별한 증상 없이 상부 보철물의 기능이 정상적으로 이루어지고 있는 경우로 설정하였 다[6].

\section{임플란트 주위 변연골 흡수량}

방사선학적 분석을 통해, 각각의 임플란트에서 시간의 흐름 에 따른 변연골 흡수량을 조사하였다. 임플란트 보철물 장착 직 후 방사선 사진을 기준으로 하여 보철 하중 1 년 후와 최종 경과 관찰 시점의 변연골 흡수량을 측정하였다. 방사선 검사 종류는 치근단 방사선 사진과 파노라마 촬영 검사만을 대상으로 하였 다. 변연골 흡수량 계산을 위해 임플란트의 최상부의 platform level과 관측되는 임플란트와 변연골 접촉점의 최상방점까지의 거리를 측정하였으며, 각 임플란트의 근심부와 원심부를 따로 측정한 후 평균값을 구하였다.

\section{통계적 분석}

SPSS Statistics ver. 17.0 (SPSS Inc., Chicago, IL, USA) 프로 그램을 이용하여 통계 분석을 시행하였다. 임플란트의 보철물 장착 1 년 후와 최종 변연골 흡수량을 측정하여 평균과 표준 편 차를 계산하였다. GS II와 GS III에서 평균 변연골 흡수량을 독

Table 1. Types of bone graft

\begin{tabular}{cccc}
\hline $\begin{array}{c}\text { Types of } \\
\text { implant }\end{array}$ & $\begin{array}{c}\text { Guided bone } \\
\text { regeneration }\end{array}$ & Sinus graft & Total \\
\hline GS II & 39 & 9 & 48 \\
GS III & 26 & 18 & 44 \\
Total & 65 & 27 & 92 \\
\hline
\end{tabular}

GS II: Osstem, Busan, Korea; GS III: Osstem.
립 t-검정(independent sample t-test)을 이용하여 임플란트 시스템 간 유의미한 차이가 있는지 분석하였다 $(p=0.05)$.

\section{결 과}

선별된 환자들은 총 36명으로 남자 25명, 여자 11명이었다. 환자들에게 식립된 임플란트는 총 101개로 GS II 59개, GS III 42개였다. 환자의 연령은 17 세부터 85 세까지로 다양했고, 평균 연령은 51세였다. 1회법으로 식립된 임플란트는 GS II에서 18 개, GS III에서 8개였고, 2회법으로 식립된 임플란트는 GS II에 서 41개, GS III에서는 34개로, 대부분 2회법으로 식립되었다. 식립 시 동반 수술로는 GS II의 경우 39개에서 골유도재생술 (guided bone regeneration, GBR)이 동반되었고, 9개에서 상 악동골이식이 동반되었다. GS III의 경우 26개에서 GBR이, 18 개에서 상악동골이식이 동반되었다. 사용된 골이식재는 Orthoblast II (SeaSpine, Carlsbad, CA, USA)가 가장 많았고, 차폐막 은 Ossix plus (Datum Dental Ltd., Lod, Israel)가 가장 많았다. 식립된 임플란트의 직경은 $5 \mathrm{~mm}$ 가 가장 많았고 길이는 13.0 $\mathrm{mm}, 11.5 \mathrm{~mm}$ 가 많이 식립되었다. 임플란트 초기 및 이차 안정 도(implant stability quotient, ISQ)는 Osstell Mentor (Osstell, Gothenburg, Sweden)를 사용하여 측정되었으며 GS II의 평균 초기 안정도는 상악 61.6, 하악 73.0이었고 GS III는 상악 66.2, 하악 63.7이었다. 평균 이차 안정도는 GS II는 상악 68.8, 하악 73.3이었고 GS III는 상악 76.1, 하악 69.5였다(Table 1-5).

임플란트 수술 직후부터 보철물 장착 전까지 발생한 초기 합 병증은 심한 통증이 4 개의 임플란트에서 관찰되었고 술 후 감 염, 신경 손상, 출혈 등과 같은 합병증은 발생하지 않았다. 보철 물 장착 이후 발생한 지연 합병증으로는 나사 풀림이 2개에서

Table 3. Diameter of implants

\begin{tabular}{lrrr}
\hline Diameter $(\mathbf{m m})$ & GS II & GS III & Total \\
\hline 3.5 & 7 & 2 & 9 \\
4.0 & 23 & 13 & 36 \\
4.5 & 8 & 6 & 14 \\
5.0 & 21 & 21 & 42 \\
Total & 59 & 42 & 101 \\
\hline
\end{tabular}

GS II: Osstem, Busan, Korea; GS III: Osstem.

Table 2. Types of implant placement

\begin{tabular}{|c|c|c|c|c|c|}
\hline \multirow{2}{*}{ Implant system } & \multicolumn{2}{|c|}{ GS II } & \multicolumn{2}{|c|}{ GS III } & \multirow{2}{*}{ Total } \\
\hline & One-stage & Two-stage & One-stage & Two-stage & \\
\hline Number & 18 & 41 & 8 & 34 & 101 \\
\hline
\end{tabular}

GS II: Osstem, Busan, Korea; GS III: Osstem. 
관찰되었고, 임플란트 주위염이 6개, 임플란트 고정체 노출이 4 개의 임플란트에서 관찰되었다. 또한 대합치의 교합외상이 3개 의 임플란트에서 관찰되었다(Table 6).

임플란트 식립 시점 기준으로 경과관찰 기간은 최소 1 년에서 최대 12년까지로 평균 6.15년이었다(Table 7).

관찰 기간 중에 제거된 임플란트는 101 개 중 8 개로, $92.1 \%$ 의 생존율을 보였다. GS II가 4개, GS III 4개가 제거되어 각 시스 템별 생존율은 GS II 93.2\%, GS III 90.5\%였다. 식립 위치에 따 른 평가에서는 실패한 GS II 4개 중 1 개는 상악, 3 개는 하악에 식립된 임플란트여서 각각의 생존율은 상악 $96.8 \%$, 하악 $89.3 \%$ 였고, 실패한 GS III 4개는 모두 하악에 식립된 임플란트여서 상

Table 4. Length of implants

\begin{tabular}{lrcc}
\hline Length $(\mathbf{m m})$ & GS II & GS III & Total \\
\hline 7.0 & 5 & 5 & 10 \\
8.5 & 10 & 8 & 18 \\
10.0 & 13 & 4 & 17 \\
11.5 & 14 & 11 & 25 \\
13.0 & 15 & 14 & 29 \\
15.0 & 2 & 0 & 2 \\
Total & 59 & 42 & 101 \\
\hline
\end{tabular}

GS II: Osstem, Busan, Korea; GS III: Osstem.

Table 5. Implant primary and secondary stability

\begin{tabular}{llcc}
\hline Implant stability quotient & Primary & Secondary \\
\hline \multirow{2}{*}{ GS II } & Maxilla & 61.6 & 68.8 \\
& Mandible & 73.0 & 73.3 \\
\multirow{2}{*}{ GS III } & Total & 66.6 & 71.3 \\
& Maxilla & 66.2 & 76.1 \\
\multirow{2}{*}{ Total average } & Mandible & 63.7 & 69.5 \\
& Total & 65.2 & 73.5 \\
\hline
\end{tabular}

GS II: Osstem, Busan, Korea; GS III: Osstem.
악의 생존율은 $100 \%$, 하악의 생존율은 $75.0 \%$ 로 나타났다. 보철 기능 1 년 후와 최종 경과관찰 시 변연골 흡수량을 평가하였다. GS II의 경우 표본 59개 중 실패한 4개와 경과관찰이 잘 이루어 지지 않은 3 개를 제외한 52 개가 분석에 포함되었고, GS III의 경우 표본 42 개 중 실패한 4 개를 제외한 38 개가 분석에 포함되 었다. 하중 1 년 후 전체 임플란트의 평균 변연골 흡수량은 0.13 $\mathrm{mm}$ 였고 GS II $0.23 \mathrm{~mm}$, GS III $0.05 \mathrm{~mm}$ 였으며 통계적으로 유의성 있는 차이를 보였다 $(p<0.05)$. 하중 이후 최종 경과 관찰 시 전체 임플란트의 평균 변연골 흡수량은 $0.4 \mathrm{~mm}$ 였고 GS II

Table 6. Complications of implants

\begin{tabular}{|c|c|c|c|c|}
\hline \multicolumn{2}{|c|}{ Complication } & GS II & GS III & Total \\
\hline \multicolumn{2}{|l|}{ Screw loosening } & 2 & 0 & 2 \\
\hline \multicolumn{2}{|l|}{ Fracture } & 0 & 0 & 0 \\
\hline \multicolumn{2}{|l|}{ Peri-implantitis } & 4 & 2 & 6 \\
\hline \multicolumn{2}{|c|}{ Implant delayed failure } & 0 & 0 & 0 \\
\hline \multicolumn{2}{|c|}{ Implant fixture exposure } & 4 & 0 & 4 \\
\hline \multicolumn{2}{|c|}{ Pain } & 4 & 0 & 4 \\
\hline \multicolumn{2}{|c|}{ Peri-implant gingivitis } & 0 & 0 & 0 \\
\hline \multicolumn{2}{|l|}{ Prosthetics exfoliation } & 0 & 0 & 0 \\
\hline \multicolumn{2}{|l|}{ Hematoma } & 0 & 0 & 0 \\
\hline \multicolumn{2}{|l|}{ Maxillary sinusitis } & 0 & 0 & 0 \\
\hline \multicolumn{2}{|c|}{ Temporomandibular disorder } & 0 & 0 & 0 \\
\hline \multicolumn{2}{|l|}{ Bleeding } & 0 & 0 & 0 \\
\hline \multicolumn{2}{|c|}{ Antagonist traumatic occlusion } & 0 & 3 & 3 \\
\hline \multicolumn{2}{|l|}{ Total number } & 14 & 5 & 19 \\
\hline \multicolumn{5}{|c|}{ GS II: Osstem, Busan, Korea; GS III: Osstem. } \\
\hline \multicolumn{5}{|l|}{ Table 7. Follow-up period } \\
\hline Follow-up period (y) & Minimum & \multicolumn{2}{|c|}{ Maximum } & Average \\
\hline Total & 1 & \multicolumn{2}{|c|}{12} & 6.15 \\
\hline GS II & 1 & \multicolumn{2}{|c|}{12} & 6.21 \\
\hline GS III & 1.5 & \multicolumn{2}{|c|}{8.75} & 6.08 \\
\hline
\end{tabular}

GS II: Osstem, Busan, Korea; GS III: Osstem.

Table 8. Implant survival rate and marginal bone loss ( $\mathrm{mm})$

\begin{tabular}{|c|c|c|c|c|c|}
\hline & \multicolumn{2}{|c|}{ GS II } & \multicolumn{2}{|c|}{ GS III } & \multirow{2}{*}{ Total } \\
\hline & Maxilla & Mandible & Maxilla & Mandible & \\
\hline Survival rate (\%) & $30 / 31(96.8)$ & $25 / 28(89.3)$ & $26 / 26(100.0)$ & $12 / 16(75.0)$ & $93 / 101(92.1)$ \\
\hline \multicolumn{6}{|c|}{ Marginal bone loss (failure excluded) } \\
\hline 1 year after placement $(\mathrm{mm})$ & 0.24 & 0.22 & 0.04 & 0.06 & 0.13 \\
\hline Average & \multicolumn{2}{|c|}{0.23} & \multicolumn{2}{|c|}{0.05} & \\
\hline At the final (mm) & 0.77 & 0.24 & 0.4 & 0.06 & 0.4 \\
\hline Average & \multicolumn{2}{|c|}{0.51} & \multicolumn{2}{|c|}{0.29} & \\
\hline
\end{tabular}

Values are presented as number (survival/total) (\%) or number only.

GS II: Osstem, Busan, Korea; GS III: Osstem. 
$0.51 \mathrm{~mm}$, GS III $0.29 \mathrm{~mm}$ 였으나 통계적으로 유의성은 없었다 ( $p>0.05$; Table 8$)$.

최종 경과 관찰 시 총 101 개의 임플란트 중, Albrektsson의 임플란트 성공 기준에 부합하는 임플란트는 83 개로, $82.2 \%$ 의 성공률을 보였다. 실패한 18 개의 임플란트 중 GS II가 10 개, GS III가 8개였고, 각 시스템별 성공률은 GS II 83.1\% (49개/59개), GS III 81.0\% (34개/42개)였다(Table 9).

생존율과 임플란트 폭경, 길이와의 관계를 조사하였다. 총 101 개의 임플란트의 폭경은 $3.5 \mathrm{~mm}$ 개, $4.0 \mathrm{~mm} \mathrm{35}$ 개, 4.5 $\mathrm{mm} 14$ 개, $5.0 \mathrm{~mm}$ 43개가 사용되었고 각각의 실패 개수는 3.5 $\mathrm{mm}$ 는 0 개, $4.0 \mathrm{~mm}$ 는 5 개, $4.5 \mathrm{~mm}$ 는 2 개, $5.0 \mathrm{~mm}$ 는 1 개로, 생존율로는 $3.5 \mathrm{~mm} \mathrm{100 \% ,4.0} \mathrm{mm} \mathrm{85.7 \% ,} 4.5 \mathrm{~mm} \mathrm{85.7 \% ,5.0}$ $\mathrm{mm}$ 97.7\%로 나타났다(Table 10).

101 개의 임플란트의 길이는 $7.0 \mathrm{~mm} \mathrm{10}$ 개, $8.5 \mathrm{~mm} 18$ 개, $10.0 \mathrm{~mm} 17$ 개, $11.5 \mathrm{~mm} \mathrm{25}$ 개, $13.0 \mathrm{~mm}$ 29개, $15.0 \mathrm{~mm}$ 2개 가 사용되었고, 각각의 실패 개수는 $7.0 \mathrm{~mm} 3$ 개, $8.5 \mathrm{~mm}$ 3개, $10.0 \mathrm{~mm} \mathrm{1}$ 개, $11.5 \mathrm{~mm}$ 0개, $13.0 \mathrm{~mm}$ 1개, $15.0 \mathrm{~mm}$ 0개로 조사되었으며, 생존율로는 $7.0 \mathrm{~mm} 70 \%, 8.5 \mathrm{~mm} \mathrm{83.3 \% ,10.0}$

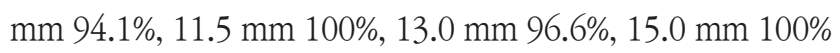
로 나타났다(Table 11).

식립 방법에 따른 생존율과 성공률을 살펴보면, 1 회법으로 식 립된 26개의 임플란트 중 24개가 생존하고 2개가 실패하였으 며, 23개가 성공하고 3개가 실패하였다. 2회법으로 식립된 75

Table 9. Implant success of each implant system

\begin{tabular}{lccc}
\hline Implant system & GS II & GS III & Total \\
\hline Failure & 10 & 8 & 18 \\
Total & 59 & 42 & 101 \\
Success rate $(\%)$ & 83.1 & 81.0 & 82.2 \\
\hline
\end{tabular}

GS II: Osstem, Busan, Korea; GS III: Osstem.
개의 임플란트 중 69 개가 생존하고 6 개가 제거되었으며, 60 개 가 성공하고 15 개가 실패하였다. 생존율로는 1 회법이 $92.3 \%, 2$ 회법이 $92 \%$, 성공률은 1회법이 $88.5 \%, 2$ 회법이 $80 \%$ 로 생존율 은 유사했으나, 성공률은 1회법이 2회법보다 확연히 더 높게 나 왔다. 그러나 생존율과 성공률 모두 식립 방법에 따라 통계적으 로 유의성 있는 차이는 없었다 $(p>0.05)$. 골이식 여부와 방법 에 따른 생존율과 성공률을 살펴보면, 골이식을 하지 않은 18 개의 임플란트 중 17 개가 생존 및 성공하였고 1 개만 실패하였 다. GBR을 시행한 65 개의 임플란트 중, 58 개가 생존하고 7 개 가 제거되었으며, 49 개가 성공하고 16 개가 실패하였다. 상악동 골이식을 시행한 18 개의 임플란트 중 17 개가 생존 및 성공하 였고 1개만 실패하였다. 골이식을 하지 않은 경우, GBR을 시행 한 경우, 상악동골이식을 시행한 경우의 생존율은 각각 $94.4 \%$, $89.2 \%, 94.4 \%$ 이고 성공률은 각각 $94.4 \%, 75.4 \%, 94.4 \%$ 로 측정 되어, $\mathrm{GBR}$ 을 시행한 군에서 생존율과 성공률이 매우 큰 폭으로 감소하였다. 그러나 생존율과 성공률 모두 골이식 유무나 방법 에 따른 통계적 유의성은 없었다( $p>0.05)$.

식립 위치에 따른 생존율과 성공률을 살펴보면, 상악에 식립 된 55 개의 임플란트 중, 54 개가 생존하고 1 개만 제거되었으며, 47 개가 성공하고 8 개가 실패하였다. 하악에 식립된 46개의 임 플란트 중 39개가 생존하고 7 개가 제거되었으며, 36개가 성공 하고 10 개가 실패하였다. 상악, 하악의 생존율은 각각 $98.2 \%$, $84.8 \%$ 로 나타났고 성공률은 각각 $85.5 \%, 78.3 \%$ 로 나타났다. 상 악의 생존율과 성공률이 모두 하악보다 큰 차이로 높았으며, 하 악에 비해 상악은 생존율보다 성공률이 큰 차이로 감소하였다. 생존율은 상악의 생존율이 하악보다 통계적으로 유의하게 높았 으며 $(p<0.05)$, 성공률은 식립 위치에 따른 통계적 유의성은 없 었다 $(p>0.05)$.

식립 시 Osstell Mentor를 사용하여 초기 안정도가 측정된 75 개 임플란트의 ISQ 값에 따른 임플란트 실패의 연관성을 평가하

Table 10. Implant survival of each diameter

\begin{tabular}{lccccc}
\hline Implant diameter $(\mathbf{m m})$ & $\mathbf{3 . 5}$ & $\mathbf{4 . 0}$ & $\mathbf{4 . 5}$ & $\mathbf{5 . 0}$ & Total \\
\hline Extracted & 0 & 5 & 2 & 1 & 8 \\
Total & 9 & 35 & 14 & 43 & 101 \\
Survival rate (\%) & 100 & 85.7 & 85.7 & 97.7 & 92.1 \\
\hline
\end{tabular}

Table 11. Implant survival of each length

\begin{tabular}{lccccccc}
\hline Implant length $(\mathbf{m m})$ & $\mathbf{7 . 0}$ & $\mathbf{8 . 5}$ & $\mathbf{1 0 . 0}$ & $\mathbf{1 1 . 5}$ & $\mathbf{1 3 . 0}$ & $\mathbf{1 5 . 0}$ & Total \\
\hline Extracted & 3 & 3 & 1 & 0 & 1 & 0 & 8 \\
Total & 10 & 18 & 17 & 25 & 29 & 2 & 101 \\
Survival rate (\%) & 70 & 83.3 & 94.1 & 100 & 96.6 & 100 & 92.1 \\
\hline
\end{tabular}


였다. 생존한 임플란트와 제거된 임플란트의 초기 안정도는 각 각 평균 $66.87,56.14$ 였으며 통계적으로 유의성 있는 차이를 보 였다 $(p<0.05)$. 성공한 임플란트와 실패한 임플란트의 식립 시 평균 ISQ 값은 각각 $67.14,59.16$ 이었으나 통계적으로 유의성 있는 차이는 없었다 $(p>0.05)$.

1 회법과 2회법에 따른 변연골 흡수량 차이를 살펴보면, 1 회 법으로 식립된 임플란트 21 개의 평균 보철 1 년 후 변연골 흡수 량은 $0.12 \mathrm{~mm}$, 최종 변연골 흡수량은 $0.15 \mathrm{~mm}$ 였고, 2회법으 로 식립된 임플란트 69개의 평균 보철 1년 후 변연골 흡수량은 $0.13 \mathrm{~mm}$, 최종 변연골 흡수량은 $0.48 \mathrm{~mm}$ 였다. 보철 1년 후와 최종 변연골 소실량 모두 1회법보다 2회법이 더 큰 변연골 소실 량을 보였는데, 보철 1년 후 변연골 소실량은 통계적으로 유의 성 있는 차이는 없었다 $(p>0.05)$. 그러나 최종 변연골 소실량은 1 회법 $0.15 \mathrm{~mm}, 2$ 회법 $0.48 \mathrm{~mm}$ 로 통계적으로 유의성 있는 차 이를 보였다 $(p<0.05$; Table 12).

임플란트 폭경에 따른 변연골 흡수량 차이를 살펴보면, 직경 $3.5 \mathrm{~mm}$ 의 임플란트 10 개의 평균 보철 1 년 후 변연골 흡수량은 $0.15 \mathrm{~mm}$, 최종 변연골 흡수량은 $0.17 \mathrm{~mm}$ 였고, 직경 $4.0 \mathrm{~mm}$ 의 임플란트 31 개의 평균 보철 1 년 후 변연골 흡수량은 0.12 $\mathrm{mm}$, 최종 변연골 흡수량은 $0.37 \mathrm{~mm}$ 였다. 직경 $4.5 \mathrm{~mm}$ 의 임 플란트 12 개의 평균 보철 1 년 후 변연골 흡수량은 $0.38 \mathrm{~mm}$, 최 종 변연골 흡수량은 $0.62 \mathrm{~mm}$ 이며, 직경 $5.0 \mathrm{~mm}$ 의 임플란트

Table 12. Difference of marginal bone loss by implant placement method (mm)

\begin{tabular}{lccc}
\hline Implant placement method & One-stage & Two-stage & $\boldsymbol{p}$-value \\
\hline $\begin{array}{l}\text { Marginal bone loss } \\
\text { (failure excluded) }\end{array}$ & & & \\
$\quad$ 1 year after placement & 0.12 & 0.13 & 0.304 \\
$\quad$ At the final & 0.15 & 0.48 & $0.037^{\mathrm{a}}$ \\
\hline
\end{tabular}

${ }^{\mathrm{a}} p<0.05$.
41 개의 평균 보철 1 년 후 변연골 흡수량은 $0.06 \mathrm{~mm}$, 최종 변 연골 흡수량은 $0.41 \mathrm{~mm}$ 였다. 회귀분석 결과, 이러한 폭경의 차 이에 따른 보철 1년 후 변연골 소실량과 최종 변연골 소실량은 통계적으로 유의성 있는 차이를 보이지 않았다 $(p>0.05$; Table 13).

임플란트 길이에 따른 변연골 흡수량 차이를 살펴보면, 길이 $7.0 \mathrm{~mm}$ 의 임플란트 9개의 평균 보철 1년 후 변연골 흡수량은 $0.12 \mathrm{~mm}$, 최종 변연골 흡수량은 $0.11 \mathrm{~mm}$ 였고, 길이 $8.5 \mathrm{~mm}$ 의 임플란트 15 개의 평균 보철 1 년 후 변연골 흡수량은 0.23 $\mathrm{mm}$, 최종 변연골 흡수량은 $0.39 \mathrm{~mm}$ 이고, 길이 $10.0 \mathrm{~mm}$ 의 임 플란트 16 개의 평균 보철 1 년 후 변연골 흡수량은 $0.16 \mathrm{~mm}$, 최 종 변연골 흡수량은 $0.23 \mathrm{~mm}$ 였다. 길이 $11.5 \mathrm{~mm}$ 의 임플란트 25 개의 평균 보철 1 년 후 변연골 흡수량은 $0.04 \mathrm{~mm}$, 최종 변연 골 흡수량은 $0.15 \mathrm{~mm}$ 였으며 길이 $13.0 \mathrm{~mm}$ 의 임플란트 28 개 의 평균 보철 1년 후 변연골 흡수량은 $0.16 \mathrm{~mm}$, 최종 변연골 흡 수량은 $0.80 \mathrm{~mm}$ 이며, 길이 $15.0 \mathrm{~mm}$ 의 임플란트 2개는 변연골 흡수가 없었다. 회귀분석 결과, 이러한 길이의 차이에 따른 보철 1 년 후 변연골 소실량과 최종 변연골 소실량은 통계적으로 유의 성 있는 차이를 보이지 않았다 ( $p>0.05$; Table 14).

골이식 유무에 따른 변연골 소실량 차이를 알기 위해, 골이식 을 시행하지 않은 군과 $\mathrm{GBR}$ 을 시행한 군을 비교하였다. 골이 식을 시행하지 않은 12 개 임플란트의 평균 보철 1 년 후 변연골 흡수량은 $0.09 \mathrm{~mm}$ 이고 최종 변연골 흡수량은 $0.25 \mathrm{~mm}$ 였다. $\mathrm{GBR}$ 을 시행한 58 개의 임플란트의 평균 보철 1 년 후 변연골 흡 수량은 $0.17 \mathrm{~mm}$ 이고 최종 변연골 흡수량은 $0.51 \mathrm{~mm}$ 로, $\mathrm{GBR}$ 을 시행한 군에서 더 큰 변연골 흡수량을 보였다. 그러나 골이식 유무에 따른 골흡수량은 통계적으로 유의성 있는 차이를 보이 지 않았다 $(p>0.05$; Table 15).

변연골 흡수량의 임플란트 식립 위치에 따른 차이를 살펴보 면, 상악에 식립된 54 개 임플란트의 평균 보철 1년 후 변연골 흡

Table 13. Average marginal bone loss of each implant diameter

\begin{tabular}{|c|c|c|c|c|c|}
\hline Diameter (mm) & 3.5 & 4.0 & 4.5 & 5.0 & $p$-value \\
\hline \multicolumn{6}{|c|}{ Marginal bone loss (failure excluded) } \\
\hline 1 year after placement & 0.15 & 0.12 & 0.38 & 0.06 & 0.815 \\
\hline At the final & 0.17 & 0.37 & 0.62 & 0.41 & 0.781 \\
\hline
\end{tabular}

Table 14. Average marginal bone loss of each implant length

\begin{tabular}{|c|c|c|c|c|c|c|c|}
\hline Length (mm) & 7.0 & 8.5 & 10.0 & 11.5 & 13.0 & 15.0 & $p$-value \\
\hline \multicolumn{8}{|c|}{ Marginal bone loss (failure excluded) } \\
\hline 1 year after placement & 0.12 & 0.23 & 0.16 & 0.04 & 0.16 & 0 & 0.586 \\
\hline At the final & 0.11 & 0.39 & 0.23 & 0.15 & 0.80 & 0 & 0.622 \\
\hline
\end{tabular}


Won-Woong Jang, et al.

Table 15. Difference of marginal bone loss between non-grafted and guided bone regeneration (GBR) site $(\mathrm{mm})$

\begin{tabular}{cccc}
\hline Bone graft & Non-grafted & GBR & $\boldsymbol{p}$-value \\
\hline $\begin{array}{c}\text { Marginal bone loss } \\
\text { (failure excluded) }\end{array}$ & & & \\
$\quad$ 1 year after placement & 0.09 & 0.17 & 0.112 \\
$\quad$ At the final & 0.25 & 0.51 & 0.072 \\
\hline
\end{tabular}

수량은 $0.16 \mathrm{~mm}$ 이고 최종 변연골 흡수량은 $0.58 \mathrm{~mm}$ 였다. 하 악에 식립된 36개의 임플란트의 평균 보철 1 년 후 변연골 흡수 량은 $0.1 \mathrm{~mm}$ 였고 최종 변연골 흡수량은 $0.13 \mathrm{~mm}$ 로, 상악에서 더 큰 변연골 흡수량을 보였다. 상, 하악간 통계적 유의성은 보 철 1년 후 변연골 소실량의 경우 유의성은 없었으나 $(p>0.05)$ 최종 변연골 소실량은 유의성 있는 차이를 보였다 $(p<0.05$; Table 16).

\section{고 찰}

임플란트 예후에 있어서 임플란트 주위의 변연골 상태가 매 우 중요하다. 여러 연구들에서 임플란트에 힘이 가해질 때, 그 힘의 분포가 임플란트의 길이에는 영향을 받지 않으며 임플란 트 고정체의 치관부 피질골 부분에서 대부분의 고정력이 발휘 되는 것이 밝혀졌기 때문이다[7]. 임플란트 주위 변연골로부터 안정적인 고정이 이루어질 경우 하중에 잘 견디게 된다. 따라 서 하중에 잘 견디지 못하거나 세균학적 감염이 진행되는 경우 치조정 부위의 골흡수가 발생하게 되며 잘 조절되지 않을 경우 임플란트 실패로 이어질 위험성이 있다. 오래 전부터 사용되어 왔던 수많은 임플란트들의 치조정 부위에서 배 모양으로 흡수 (saucerization)되는 양상이 자주 관찰되었다. 그러나 최근에는 임플란트 디자인이나 표면의 발전으로 골흡수가 현저히 감소되 었으며 장기적으로 안정적인 결과를 보이고 있다[8].

여러 연구들에 따르면, 변연골의 흡수의 원인에는 여러 가 지 요소가 작용한다. Frost [9,10]는 임플란트에 가해지는 응력 을 골흡수의 주요한 원인으로 보고했는데, $3000 \mu \mathrm{E}$ (microstrain) 이상의 생리적 부하를 넘어서는 응력이 가해지면 병적 과부하를 야기하여 골흡수가 일어난다고 주장했다. 그 외 다른 요인들로는 임플란트 수술 시의 판막 거상으로 인한 골 노출, 골 에 드릴링 시 일시적으로 발생하는 혈액 공급의 차단과 열 등의 수술 외상, 임플란트 고정체 외 지대주 연결 시의 생물학적 폭 경, 임플란트 식립 후 창상열개 등이 있다. 골 흡수와 관련된 임 플란트 자체적인 요인으로는 임플란트 시스템 종류와 임플란트 표면 처리 방법, 임플란트 상부 나사산 형태, 임프란트-지대주 연결 방식, 임플란트와 abutment 계면 사이에 존재하는 미세간
Table 16. Difference of marginal bone loss by implant placement site (mm)

\begin{tabular}{cccc}
\hline Location & Maxilla & Mandible & $\boldsymbol{p}$-value \\
\hline $\begin{array}{c}\text { Marginal bone loss } \\
\text { (failure excluded) }\end{array}$ & & & \\
$\quad$ 1 year after placement & 0.16 & 0.1 & 0.799 \\
At the final & 0.58 & 0.13 & $<0.001$ \\
\hline
\end{tabular}

극 등이 있다[2-5,11,12]. Hermann 등[13]의 연구에 의하면, 부 드럽거나 거친 임플란트 계면의 위치뿐만 아니라, 임플란트와 abutment 사이의 미세간극의 위치가 치조정 변연골 형성에 미 치는 영향이 매우 크다고 보고하고 있다.

따라서 임상 의사가 임플란트를 선택할 때, 이러한 변연골 골 흡수가 적게 일어나는 임플란트를 선택해야 할 필요가 있고, 수 술 중 및 수술 후에도 외상을 최소화하고 임플란트에 과도한 스 트레스가 가해지지 않도록 하는 것이 매우 중요하며 장기적인 예후에 있어서도 그 변연골이 잘 유지되도록 하여야 한다.

임플란트 변연골 흡수량의 경우 Atieh 등[14]의 연구에서 platform switching된 여러 다른 연구들의 결과를 모아 보고했 는데, Cappiello 등의 연구에서는 기능 1년 후 평균 변연골 흡 수량이 $0.95 \mathrm{~mm}$ 로 보고되었고, Crespi 등의 연구에서 식립 2 년 후 평균 변연골 흡수량이 $0.73 \mathrm{~mm}$ 로 보고되었다. 이는 본 연구의 GS II와 GS III 전체의 보철 1년 후 평균 변연골 흡수량 인 $0.13 \mathrm{~mm}$ 비해 훨씬 더 큰 값인데, 본 연구에서 변연골 소실 량이 더 적게 나타난 이유로는 Osstem 사의 GS II와 GS III의 고 정체가 모두 상부에 micro-thread를 채택한 형태여서, 임플란 트 고정체의 축방향 강도를 증가시키고, 피질골에서 전단 강도 를 감소시켜 피질골 주위로 응력을 분산시키는 데 도움이 되었 기 때문으로 생각한다[4]. GS II의 경우에는 macro와 micro 나 사산을 잘 조화시킨 디자인을 채택하고 있는데, 이로 인해 피질 골과 해면골에서 모두 우수한 안정도를 얻을 수 있게 되었다. 이 를 통해 골흡수를 야기하는 주요한 원인으로 알려진 임플란트 에 가해지는 하중으로부터 더욱 안정적으로 잘 견딜 수 있게 된 것 또한 골흡수를 줄이는 데 영향을 주었을 것이다. 또한 본 연 구에 포함된 임플란트들에서는 술 후 감염이나 임플란트 주위 염과 같은 합병증의 발생이 적은 것 또한 영향을 준 것으로 생각 한다.

GS II와 GS III 간의 변연골 흡수량을 비교해보면, 하중 1 년 후 평균 변연골 흡수량에서는 GS II가 $0.23 \mathrm{~mm}$ 로 GS III의 $0.05 \mathrm{~mm}$ 보다 통계적으로 유의미하게 더 큰 흡수를 보였다 $(p$ $<0.05)$. 이는 GS III의 경우, GS II와는 다르게 taper 형태의 임 플란트이기 때문으로 생각하는데, GS II와 같은 원통형 임플란 트는 임플란트-골계면에 부적절한 전단력(shear force)을 발생 
시키는 반면, GS III와 같은 taper 형의 임플란트는 원통형 디자 인에 비해 인접 골을 더 균일하게 압축시키며 식립되는 효과가 있어 임플란트-골계면에 압축 응력(compressive force)이 발휘 될 수 있다[15]. 그러나 하중 이후 최종 경과 관찰 시 평균 변연 골 흡수량에서는 여전히 GS II가 $0.51 \mathrm{~mm}$ 로 GS III의 $0.29 \mathrm{~mm}$ 보다 크기는 하나, 통계적으로 유의미한 차이는 보이지 않았다 ( $p>0.05$; Table 8). 이는 GS II와 GS III 모두 장기간의 임상적 인 예후는 모두 큰 차이 없이 만족스러운 결과를 보일 수 있음을 의미한다.

임플란트 치료 관련 합병증들은 매우 다양하다. 통증, 치은 발 적, 종창 및 출혈 등 임플란트 주위 염증 반응의 징후를 나타내 는 경우가 식립 1년 후 $12 \%$ 라는 Gotfredsen과 Karlsson [16] 의 연구가 있었고 Behneke 등[17]이 보고한 바로는 9\%의 환자 에서 임플란트 식립 5년 이내에 임플란트 주위염을 진단받는다 고 하였다. 그 외에 보철 및 기술적 합병증으로는 veneer 재료 의 chipping이 가장 흔한 합병증으로 나타났고(5년 이내 $13.5 \%$ 발생), 두 번째로 흔한 합병증은 나사 유지 고정성 보철(screwretained fixed dental prosthese)에서 나사 구멍을 막아둔 수 복물이 상실되는 것으로, 5 년 이내에 $5.4 \%$ 가 나타난 것으로 보 고되었다. 세 번째로는 지대주나 교합면의 나사가 느슨해지는 것으로, 5 년 내에 $5.3 \%$ 정도에서 발생하는 것으로 조사되었다 [18]. 본 연구에서 나타난 합병증들 중에서는 임플란트 주위염 이 6개 임플란트에서 보고되어 가장 많이 나타났고, 임플란트 고정체 노출, 심한 동통이 각각 4개로 두 번째로 많이 보고되었 다. 보철적 합병증으로는 본 연구에서는 대합치들에 의한 교합 외상이 3 개로 가장 많이 발생되었다.

본 연구에서 조사된 임플란트 101 개의 생존율은 $92.1 \%$ 였 으며 평균 관찰 기간은 6.15년이었다. Pjetursson 등[11]의 systemic review에 따르면 평균 5년간의 생존율은 논문에 따 라 $86.3 \%$ 에서 $100 \%$ 로 나타났다. 전체적으로 식립된 4,266개 의 임플란트 중 216개가 상실되었고, Poisson regression을 이 용해 논문의 전체적인 5 년 생존율을 평가한 결과 평균 $95.6 \%$ 라 고 보고하였다. 한편 10 년의 경과 관찰 기간을 기준으로 연구 한 논문들을 다른 그룹으로 묶어 분석한 결과 10 년 평균 생존율 은 $80.1 \%$ 에 그쳤다. 저자 등이 시행한 본 논문에서는 최대 12 년 까지 관찰된 증례까지 포함되었는데 systemic review에서 5년 평균 생존율 $95.6 \%$ 에서 10년 평균 생존율 $80.1 \%$ 까지 급격하 게 떨어진 것을 고려할 때, 본 논문의 임플란트 생존율이 $92.1 \%$ 로 보고된 것은 기존의 연구들에 비해 저조한 성적은 아닌 것으 로 생각한다. 임플란트의 성공은 임플란트 보철물 장착 이후 관 찰 기간 동안 합병증 없이 유지된 경우로 정의하였는데, 6 개의 논문에 포함된 464명의 환자, 평균 경과 관찰 기간이 5년인 경 우로 하였을 때, 평균 성공률은 $66.4 \%$ 였다. 이는 5 년 이내에는
주요한 합병증들 중 최소한 하나 이상이 발생하였다는 것을 의 미한다. 본 연구에서 평균 6.15년의 관찰 기간 동안 성공률은 $82.2 \%$ 로, Pjetursson 등[11]의 systemic review에 비해 더 높게 나왔는데, 이는 systemic review에 포함된 논문들에서 임플란 트 주위 탐침, 출혈 지수, 치주낭 측정 등 염증 지수를 철저히 평 가하였지만, 본 연구는 후향적 의무기록을 토대로 정리하였기 때문에 증상 및 이상징후에 대한 엄격한 평가가 잘 이루어지지 않았고 비교적 증상이 확실하고 심한 경우에만 합병증으로 기 록되었기 때문에 상대적으로 임플란트 실패가 더 적게 탐지된 것으로 생각한다. 본 연구에서 제거된 임플란트 8 개 중 4 개에서 임플란트 주위염이 발병된 것으로 나타났고, 8 개 중 3 개는 교합 외상이 존재하였던 것으로 나타났다. 따라서 본 연구에서의 임 플란트 발거의 주요한 요인은 임플란트 주위염과 교합외상이었 다.

총 36명에게 식립된 101 개의 임플란트에서 8개의 실패가 보 고되었으며, 누적 생존율은 92.1\%로 나타났다. 시스템별 생존 율은 GS II의 경우 59개 중 4 개, GS III는 42 개 중 4 개가 제거되 어 각 GS II $93.2 \%$, GS III 90.5\%로 나타났다.

임플란트 시스템 Osstem GS II, GS III 의 단기간의 변연골 흡 수량은 GS II가 GS III에 비해 유의미하게 컸으나, 장기간 임상 적인 예후는 모두 만족스러운 결과를 보였으며, 변연골 소실량 에서 유의한 차이를 보이지 않았다. 따라서 이후 개발되어 최근 에 많이 사용되고 있는 TS system의 임상 성적도 양호한 결과를 보일 것으로 추정된다.

\section{CONFLICTS OF INTEREST}

The authors declare that they have no competing interests.

\section{ORCID}

\author{
Won-Woong Jang \\ https://orcid.org/0000-0003-1172-4795 \\ Dong-Woo Kang \\ https://orcid.org/0000-0002-0118-0053 \\ Young-Kyun Kim \\ https://orcid.org/0000-0002-7268-3870
}

\section{REFERENCES}

1. Kim JH, Kim YK, Bae JH. Retrospective clinical study on sinus bone graft and tapered-body implant placement. J Korean Assoc Oral Maxillofac Surg 2013;39:77-84. doi: 
10.5125/jkaoms.2013.39.2.77.

2. Yoon WJ, Kim SG, Oh JS, You JS, Jeong KI, Lim SC, Jeong MA. Comparative study on the osseointegration of implants in dog mandibles according to the implant surface treatment. J Korean Assoc Oral Maxillofac Surg 2016;42:345351. doi: 10.5125/jkaoms.2016.42.6.345.

3. Jeong KI, Kim YK, Moon SW, Kim SG, Lim SC, Yun PY. Histologic analysis of resorbable blasting media surface implants retrieved from humans: a report of two cases. J Korean Assoc Oral Maxillofac Surg 2016;42:38-42. doi: 10.5125/jkaoms.2016.42.1.38.

4. Geramizadeh M, Katoozian H, Amid R, Kadkhodazadeh M. Three-dimensional optimization and sensitivity analysis of dental implant thread parameters using finite element analysis. J Korean Assoc Oral Maxillofac Surg 2018;44:5965. doi: 10.5125/jkaoms.2018.44.2.59.

5. Hurson S. Use of authentic, integrated dental implant components vital to predictability and successful longterm clinical outcomes. Compend Contin Educ Dent 2016;37:450-455; quiz456.

6. Albrektsson T, Zarb G, Worthington P, Eriksson AR. The long-term efficacy of currently used dental implants: a review and proposed criteria of success. Int J Oral Maxillofac Implants 1986;1:11-25.

7. Pierrisnard L, Renouard F, Renault P, Barquins M. Influence of implant length and bicortical anchorage on implant stress distribution. Clin Implant Dent Relat Res 2003;5:254262. doi: 10.1111/j.1708-8208.2003.tb00208.x.

8. Merheb J, Quirynen M, Teughels W. Critical buccal bone dimensions along implants. Periodontol 2000 2014;66:97105. doi: 10.1111/prd.12042.

9. Frost HM. Vital biomechanics: proposed general concepts for skeletal adaptations to mechanical usage. Calcif Tissue Int 1988;42:145-156. doi: 10.1007/BF02556327.

10. Frost HM. Mechanical adaptation. Frost's mechanostat theory. In: Martin RB, Burr DB, editors. Structure, function, and adaptation of compact bone. New York: Raven Press; 1989.
11. Pjetursson BE, Thoma D, Jung R, Zwahlen M, Zembic A. A systematic review of the survival and complication rates of implant-supported fixed dental prostheses (FDPs) after a mean observation period of at least 5 years. Clin Oral Implants Res 2012;23 Suppl 6:22-38. doi: 10.1111/j.16000501.2012.02546.x.

12. King GN, Hermann JS, Schoolfield JD, Buser D, Cochran DL. Influence of the size of the microgap on crestal bone levels in non-submerged dental implants: a radiographic study in the canine mandible. J Periodontol 2002;73:11111117. doi: 10.1902/jop.2002.73.10.1111.

13. Hermann JS, Cochran DL, Nummikoski PV, Buser D. Crestal bone changes around titanium implants. A radiographic evaluation of unloaded nonsubmerged and submerged implants in the canine mandible. J Periodontol 1997;68:11171130. doi: 10.1902/jop.1997.68.11.1117.

14. Atieh MA, Ibrahim HM, Atieh AH. Platform switching for marginal bone preservation around dental implants: a systematic review and meta-analysis. J Periodontol 2010;81:1350-1366. doi: 10.1902/jop.2010.100232.

15. Glauser R, Sennerby L, Meredith N, Rée A, Lundgren A, Gottlow J, Hämmerle CH. Resonance frequency analysis of implants subjected to immediate or early functional occlusal loading. Successful vs. failing implants. Clin Oral Implants Res 2004;15:428-434. doi: 10.1111/j.16000501.2004.01036.x.

16. Gotfredsen K, Karlsson U. A prospective 5-year study of fixed partial prostheses supported by implants with machined and TiO2-blasted surface. J Prosthodont 2001;10:27. doi: 10.1111/j.1532-849X.2001.00002.x.

17. Behneke A, Behneke N, d'Hoedt B. The longitudinal clinical effectiveness of ITI solid-screw implants in partially edentulous patients: a 5-year follow-up report. Int J Oral Maxillofac Implants 2000;15:633-645.

18. Bahat O. Brånemark system implants in the posterior maxilla: clinical study of 660 implants followed for 5 to 12 years. Int J Oral Maxillofac Implants 2000;15:646-653. 